\title{
VARIABLE SCHEDULES OF IBUPROFEN FOR ANKLE SPRAINS
}

\author{
G. R. McLATCHIE, FRCS*, C. ALLISTER, FRCS, C. MacEWEN, MChB, G. HAMILTON, MBChB, H. McGREGOR, RGN,
} I. COLQUHUON, MBChB and N. J. PICKVANCE, MRCP**

Accident and Emergency Department, Glasgow Royal Infirmary

\section{ABSTRACT}

In a study of 144 patients, with Grade 1 and 2 inversion injuries to the ankle sustained in sport, treatment with a non-steroidal anti-inflammatory was considerably superior to placebo with respect to joint tenderness, level of training and injury severity. No difference in efficacy could be determined between ibuprofen $2400 \mathrm{mg}$ given in two or four equally divided daily doses. Ten patients withdrew from the study because of side effects, five from ibuprofen twice daily, three from ibuprofen four times daily and two from the placebo group. This study confirms the efficacy, flexibility and tolerability of high dose ibuprofen.

\section{INTRODUCTION}

During the last ten to fifteen years according to the Sports Council's report in 1982 more people than ever before are now actively participating in sport to fill their leisure time. This phenomenon has been associated with an increased number of sports related injuries which frequently affect the soft tissues. Although usually self limiting, such injuries can lead to considerable short term morbidity and, in the case of professional sportsmen, time lost from work.

Injury to the lateral ligament of the ankle is common in sport (Brooks et al, 1981) and is also a problem in everyday life. One estimate has suggested that each day 5,000 people in the United Kingdom sustain such an injury (Ruth, 1961).

The lateral ankle ligament is a complex of three bands, the common origin of which is the distal tip of the fibula. The anterior and posterior bands (talo fibular ligaments) both insert into the talus. The central band (the calcaneal fibular ligament) passes vertically from the fibula to the calcaneum.

Three grades of ankle inversion injury are recognised (Cass and Morrey, 1984). Grade 1 is a mild stretching of the ligament with no instability. Grade 2 is a moderate sprain with incomplete tear and mild instability. Grade 3 is a complete tear. The present study was not intended to resolve the controversy surrounding early or late surgery for Grade 3 lesions but was designed to assess the benefits of and justification for using a non-steroidal anti-inflammatory in injuries which, even if untreated, would eventually heal spontaneously.

\section{METHOD}

One hundred and forty-four sports people who had sustained Grade 1 or 2 lateral ligament inversion injuries were admitted to the study. If the injury caused gross instability or talar tilt of greater than $30^{\circ}$ under stress radiography the sufferer was not entered. Those with injuries occurring more than 72 hours before consultation were excluded as were those with a concomitant serious illness or an allergy to ibuprofen. Patients were randomly allocated in a double blind way to receive ibuprofen $600 \mathrm{mg}$ four times daily or $1200 \mathrm{mg}$ twice daily or placebo for seven days. They were assessed at the beginning, middle and end of treatment. (Days 0, 3 and 7).

*Present address:

Consultant Surgeon

The General Hospital

Hartlepool

Cleveland
* Senior Medical Adviser

The Boots Company PLC Research Department

Medical Support Services

R.3 Pennyfoot Street

Nottingham
At every consultation the investigator assessed joint tenderness, muscle movement, overall severity of injury and match fitness and these measures were recorded on descriptive rating scales.

Patients then were asked to rate on a daily basis, the degree of pain at its worst and least, nocturnal pain relief and impairment of function also using rating scales.

General demographic details and the investigators' (GRMcL, CA and CMCE) opinion of progress were collected. Side effects and reasons for withdrawal were also noted.

\section{STATISTICAL ANALYSIS}

Where a variable was recorded on an ordinal scale it was assumed that the observed data represented a categorisation of scores from some underlying continuous scale. McCullough logistic regression models were used as the data generated were not parametric which involved treating the data as a series of histograms (McCullagh, 1980). These logistic models were then used to identify differences between treatments in respect of the means and their spread. In the analysis for the study, logistic regression models were routinely considered. Where graphs have been drawn this has been using means which technically are incorrect but the levels of significance where quoted are derived from McCullough type analysis.

\section{RESULTS}

Twelve patients were excluded from analysis for reasons unconnected with treatment. These involved non-attendance after the first visit (8) and patients whose parents did not wish them to enter a study despite the fact that the patients were old enough to give their own consent (4). In general the treatment groups were well balanced in respect of all variables measured at baseline.

Over $80 \%$ of the patients were aged 30 or younger and the mean age of the groups was similar. Seventy percent of the patients were male. The mean time for injury to treatment was slightly shorter in the placebo group than in all the other groups. Almost all the patients were unable to train at the beginning of the study yet only $3 \%$ were judged to have ankle effusion. Throughout the trial all groups were similar with regard to the use of ice packs and tubigrip strapping. The data from the patient diary cards indicated that all medications were taken regularly by all groups, however, insufficient assessments were recorded by the patients to make a meaningful comment on the relative analgesic efficacy of the different treatments.

\section{Tenderness}

Joint tenderness decreased in all treatments and by day 7 there was clear evidence that the mean scores for twice and 
four times daily treated patients were significantly lower than the mean scores for those treated with placebo ( $p<$ $0.01)$. There was no significant difference between the two ibuprofen treatments (Fig. 1).

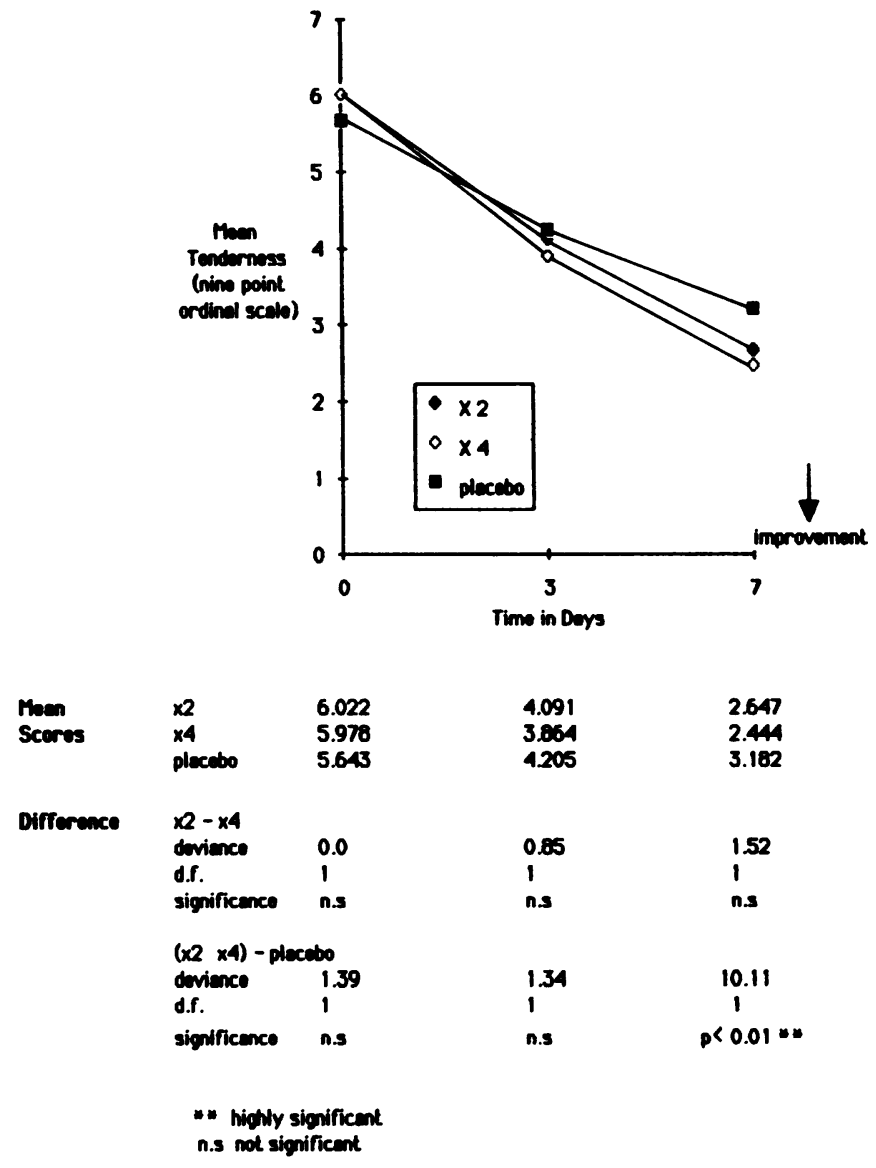

Fig. 1: Mean tenderness score over 7 days.

\section{Muscle movement}

There was an improvement in muscle movement on all treatments and although there was no significant difference between active treatments the changes appeared greater with the four times daily dose of ibuprofen (Fig. 2).

\section{Level of training possible}

By day $3,23 \%$ of patients were able to undertake some form of training. The mean scores on both the active treatments were significantly higher than for the placebo group ( $p<$ $0.01)$. This distinction remained clear at day 7 and again although there was no significant difference between the active treatments the four times daily schedule was associated with the best response (Fig. 3).

\section{Severity}

There was no significant difference at day 3 but by day 7 there was evidence of association between treatment and severity of the injury in favour of active treatment significant at the $10 \%$ level (Fig. 4).

\section{Progress}

While overall progress for each active treatment was similar there was by day 7 evidence, significant at the $10 \%$ level, that progress in the four times daily treatment group was better than in the twice daily group (Fig. 5).

\section{Side effects}

Twenty-six of the 133 patients reported side effects and 10 patients withdrew because of them. Five from the twice

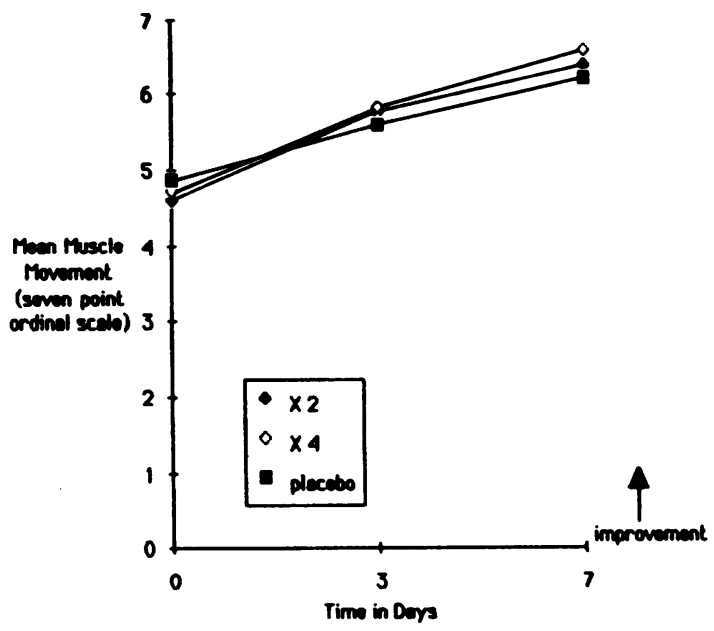

\begin{tabular}{|c|c|c|c|c|}
\hline $\begin{array}{l}\text { Mom } \\
\text { Sceres }\end{array}$ & $\begin{array}{l}x 2 \\
x 4 \\
\text { pleceoror }\end{array}$ & $\begin{array}{l}4.600 \\
4.711 \\
4.033\end{array}$ & $\begin{array}{l}5.727 \\
5.773 \\
5.564\end{array}$ & $\begin{array}{l}6.353 \\
6.556 \\
6.180\end{array}$ \\
\hline Dirfereace & $\begin{array}{l}x 2-x 4 \\
\text { dovience } \\
\text { d.f. } \\
\text { significence }\end{array}$ & $\begin{array}{l}0.0 \\
1 \\
n . s\end{array}$ & $\begin{array}{l}0.0 \\
1 \\
n . s\end{array}$ & $\begin{array}{l}1.98 \\
1 \\
n .8\end{array}$ \\
\hline & $\begin{array}{l}(\times 2 \times 4)-\text { plec } \\
\text { dovience } \\
\text { d.f. } \\
\text { slenificence }\end{array}$ & $\begin{array}{l}0.22 \\
1 \\
n .5\end{array}$ & $\begin{array}{l}0.06 \\
1 \\
n .3\end{array}$ & $\begin{array}{l}1.10 \\
1 \\
n .5\end{array}$ \\
\hline
\end{tabular}

n.s not significent

Fig. 2: Mean muscle movement over 7 days.

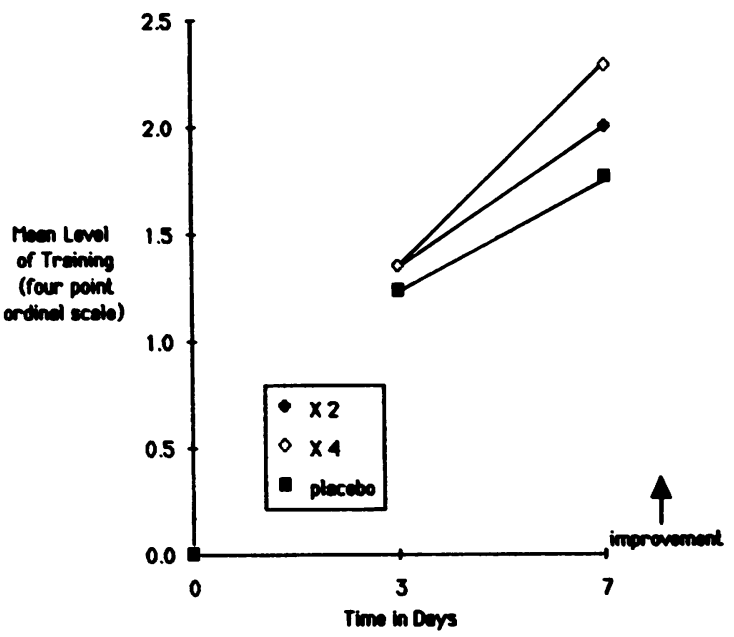

\begin{tabular}{|c|c|c|c|}
\hline $\begin{array}{l}\text { Meen } \\
\text { Sceress }\end{array}$ & $\begin{array}{l}x 2 \\
x 4 \\
\text { Diecedoo }\end{array}$ & $\begin{array}{l}1.341 \\
1.341 \\
1.231\end{array}$ & $\begin{array}{l}2.000 \\
2.278 \\
1.758\end{array}$ \\
\hline Difference & $\begin{array}{l}x 2-x 4 \\
\text { dovience } \\
\text { d.f } \\
\text { significence }\end{array}$ & $\begin{array}{l}0.87 \\
1 \\
n .3\end{array}$ & $\begin{array}{l}2.29 \\
1 \\
n .3\end{array}$ \\
\hline & $\begin{array}{l}(\times 2 \times 4)-\text { plecebo } \\
\text { devience } \\
\text { d.f }\end{array}$ & $\begin{array}{l}6.07 \\
1\end{array}$ & $\begin{array}{l}6.66 \\
1\end{array}$ \\
\hline & significance & $p<0.01 \approx$ & $p<0.01 \approx \infty$ \\
\hline
\end{tabular}

Fig. 3: Mean level of training over 7 days. 


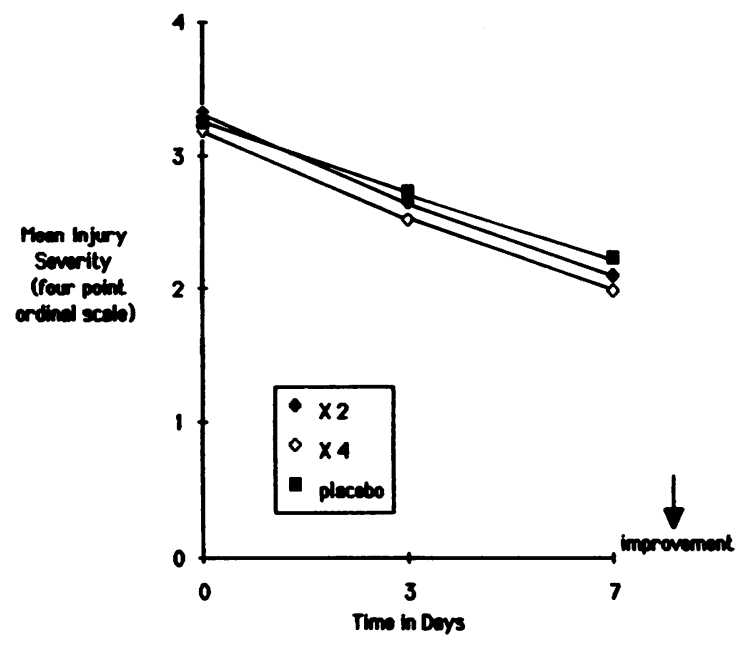

TABLE I

Baseline date

\begin{tabular}{llll}
\hline & $\begin{array}{c}\text { Ibuprofen } \\
1200 \mathrm{mg} \\
\text { Twice } \\
\text { daily }\end{array}$ & $\begin{array}{c}\text { Ibuprofen } \\
600 \mathrm{mg} \\
\text { Four times } \\
\text { daily }\end{array}$ & Placebo \\
\hline Number of patients & 45 & 45 & 42 \\
Number of males & 31 & 33 & 29 \\
Number unable to train & 44 & 42 & 40 \\
Mean age & $26.21(16-62)$ & $26.78(16-54)$ & $27.52(16-54)$ \\
Mean weight (kg) & $66.38(52-112)$ & $64.98(45-108)$ & $68.98(44-124)$ \\
Mean time since injury (hrs) & $43.85(12-72)$ & $41.10(12.72)$ & $35.53(12-192)$ \\
\hline
\end{tabular}

Sceres

$\begin{array}{ll}x 2 & 3.311 \\ x 4 & 3.178 \\ \text { diecabo } & 3.238\end{array}$

2.636

$2500 \quad 2.008$

2.718

1.972

Difrerence

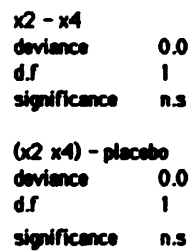

0.59

n.s

1.17

$\begin{array}{lc}2.46 & 3.02 \\ 1 & 1 \\ n .3 & p<0.10\end{array}$

n.s not sipnifiente

Fig. 4: Mean injury severity over 7 days.
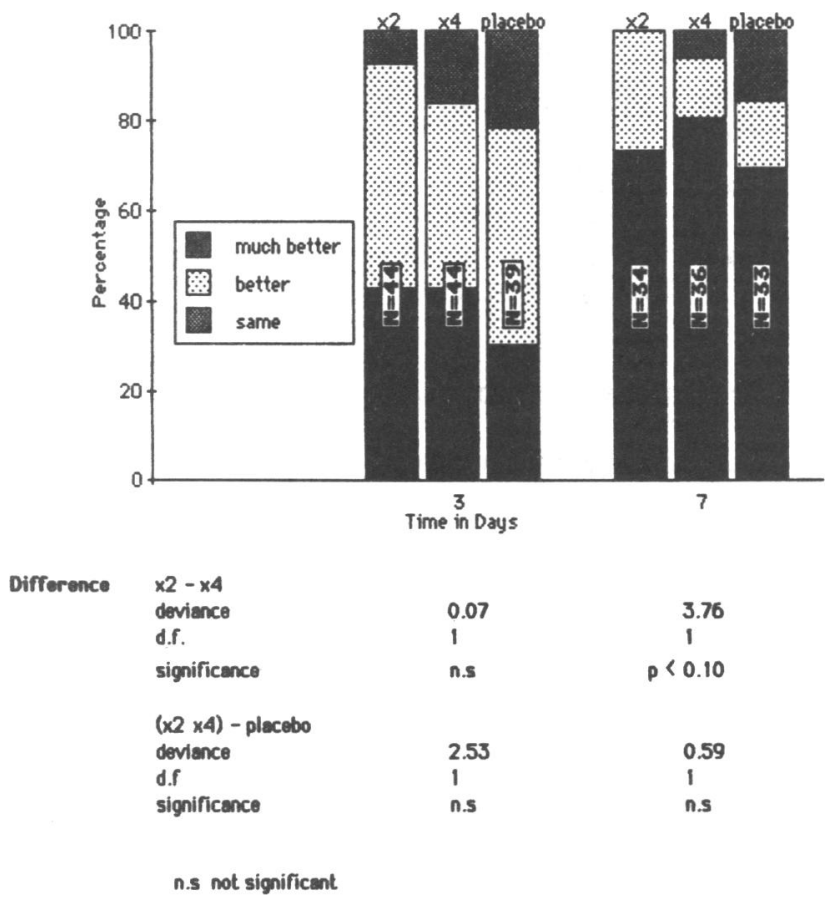

Fig. 5: Investigators' opinion of progress over 7 days.

daily group, 3 from the four times daily group and 2 from the placebo group. Gastrointestinal problems were cited in 9 of the 10 withdrawals. One patient in the four times daily group reported epistaxis. The side effects are listed in Table I and those leading to withdrawal in Table III.
TABLE \|

Side effects

\begin{tabular}{|c|c|c|c|}
\hline $\begin{array}{l}\text { Definitely } \\
\text { related to } \\
\text { trial therapy }\end{array}$ & $\begin{array}{l}\text { Possibly } \\
\text { related to } \\
\text { trial therapy }\end{array}$ & $\begin{array}{l}\text { Not related } \\
\text { to trial } \\
\text { therapy }\end{array}$ & $\begin{array}{l}\text { Relation to } \\
\text { therapy } \\
\text { unspecified }\end{array}$ \\
\hline \multicolumn{4}{|l|}{ Ibuprofen $\times 2$} \\
\hline $\begin{array}{l}\text { diarrhoea } \\
\text { heartburn } \\
\text { nausea (2) } \\
\text { epigastric pain } \\
\text { dyspepsia } \\
\text { vomiting }\end{array}$ & $\begin{array}{l}\text { nausea } \\
\text { vomiting } \\
\text { epigastric } \\
\text { discomfort }\end{array}$ & headache & $\begin{array}{l}\text { abdominal pain } \\
\text { nausea } \\
\text { vomiting }\end{array}$ \\
\hline \multicolumn{4}{|l|}{ Ibupofen $\times 4$} \\
\hline $\begin{array}{l}\text { nausea } \\
\text { epigastric } \\
\text { discomfort }\end{array}$ & $\begin{array}{l}\text { epistaxis } \\
\text { epigastric } \\
\text { discomfort } \\
\text { diarrhoea } \\
\text { nausea (2) } \\
\text { epigastric } \\
\text { burning }\end{array}$ & $\begin{array}{l}\text { feels tired } \\
\text { 'sleepy' }\end{array}$ & \\
\hline \multicolumn{4}{|l|}{ Placebo } \\
\hline Tiredness & $\begin{array}{l}\text { abdominal } \\
\text { discomfort } \\
\text { nausea } \\
\text { vomiting } \\
\text { tablets sticking } \\
\text { in throat }\end{array}$ & $\begin{array}{l}\text { cramp in } \\
\text { affected leg }\end{array}$ & \\
\hline
\end{tabular}

TABLE III

Side effects leading to withdrawal

Ibuprofen $\times 2$

1 diarrhoea, heartburn, nausea

2 epigastric pain

3 nauseated

4 dyspepsia, nausea, vomiting

5 nausea, vomiting

Ibuprofen $x 4$

1 epistaxis

2 nausea, epigastric discomfort

3 nausea

Placebo

1 abdominal discomfort

2 tablets sticking in throat, heartburn

\section{CONCLUSIONS}

This study confirms two things; that active treatment of Grade 1 and 2 inversion sprains of the lateral ligament of the ankle with ibuprofen is superior to placebo and that high dose ibuprofen is well tolerated, no matter how it is taken, provided certain exclusion criteria are observed. After 7 days, differences between the treatments were evident. 
Both active treatments were significantly better than placebo. The efficacy of the four times daily treatment appeared superior to the twice daily treatment but this finding was not statistically significant. In both ibuprofen treatment schedules the side effects profile and withdrawal rate were similar. Of the regimens evaluated, ibuprofen $600 \mathrm{mg}$ four times a day is probably the most effective, but for those patients who find this schedule inconvenient, they will still derive significant benefit from ibuprofen $1200 \mathrm{mg}$ twice daily. The findings of this study lead the authors to make the recommendation that in soft tissue injuries to the lateral ligament complex caused by sporting activity a short course of high dose ibuprofen should be considered.

\section{ACKNOWLEDGEMENTS}

We wish to thank Mr. R. Simpson and Mr. I. Swann, Consultant Surgeons in Accident and Emergency for allow- ing us to study patients in their department, and Dr. A. M. Skene, Lecturer, Department of Mathematics, University of Nottingham, for his help in undertaking the statistical analysis. Trial supplies of ibuprofen and matching placebo were provided by Medical Sciences, The Boots Company PLC, Nottingham NG2 3AA.

\section{References}

Brooks, S., Potter, B. T. and Rainey, J. B., 1981 "Treatment for partial tears of the lateral ligament of the ankle. Prospective trial". Brit.Med.J. 282: 606-607.

Cass, J. R. and Morrey, B. F., 1984 "Ankle instability: current concepts, diagnosis and treatment". Mayo Clin.Proc. 59: 165-70.

McCullagh, P., 1980 "Regression models for ordinal data (with discussion)". J.Roy.Statist.Soc. 42: 109-142.

Ruth, C. J., 1961 "Surgical treatment of injuries of the collateral ligaments of the ankle". J.Bone Joint Surg. 43A: 229-39.

Sports Council, 1982 "Sport in the Community ... the next ten years". Sports Council Report: 18-19.

\section{BOOK REVIEW}

Title: FLEXOR TENDON INJURIES

Author: Lawrence H. Schneider, MD

Publishers: $\quad$ Little, Brown \& Co.
Price: $\$ 42.50$
177 pages
Illustrations and Index

The flexor tendons of the fingers are often injured in sport - especially Rugby football — where profundus avulsions sometimes occur.

This monograph is the most comprehensive work on the flexor apparatus to date.

Dr. Lawrence Schneider has barely missed a trick in the history and management of injuries to the flexor apparatus and his bibliography is very comprehensive.

The only points one can add are as follows -

The distal profundus entrapment syndrome with the classical physical sign of loss of active flexion of the terminal phalanx when the proximal phalanx is flexed is sometimes seen after partial rupture of the profundus.

In describing the Kleinert banding technique it is surely logical after repair of a profundus tendon in any of the ulnar three digits to band all three since this part of the profundus has a mass action effect.

Finally in the matter of salvage procedures a very useful manoeuvre is to combine the Paneva-Holevitch loop anastomosis of profundus to superficialis in the palm with a silicone elastomer tendon within the digital flexor sheath. At a second procedure some ten weeks later one tendon is divided at the wrist and re-anchored to the tip of the finger by attaching the tendon to the withdrawn silicone elastomer tendon. Only one anastomosis is then necessary at the terminal phalanx. We have found this a most rewarding manoeuvre.

The bibliography is extensive so as well as the subject index an author index would prove very useful.

This book is a winner and will be particularly appreciated by all Hand Surgeons as well as those in training with an interest in this branch of surgery.

B. Helal, FRCS, MChOrth 